\title{
The lytic transition of Epstein-Barr virus is imitated by recombinant B-cells
}

\author{
M. Marschall ${ }^{2}$, P. Alliger ${ }^{2}$, F. Schwarzmann', C. Bogedain ${ }^{1}$, M. Brand ${ }^{2}$, B. Reichelt ${ }^{2}$, \\ G. Glaser ${ }^{1}$, and $\mathbf{H}$. Wolf ${ }^{1}$ \\ ${ }^{1}$ Institut für Medizinische Mikrobiologie und Hygiene, Universität Regensburg, \\ Regensburg \\ ${ }^{2}$ Max von Pettenkofer-Institut für Hygiene und Medizinische Mikrobiologie, \\ Ludwig-Maximilians-Universität München, München, Federal Republic of Germany
}

Accepted August 27, 1992

\begin{abstract}
Summary. Lytic transition of Epstein-Barr virus (EBV) is initiated by distinct immediate early regulators of the viral cycle, in synchronization to temporary, permissive conditions during host cell differentiation. We developed eukaryotic vectors suitable to imitate the processes involved in lytic transition in cell culture systems. Two stable B cell lines were established: R59Z activator cells were used to induce lytic EBV expression in a constitutive manner by the production of the BZLF 1 trans-activator (Zta). R7-57 reporter cells, on the other hand, signaled induced activity of the lytic origin of EBV replication (ori $L y t$ ). Different modes, like chemical induction, lytic superinfection with EBV and single gene trans-activation converted the recombinant ori $L y t$ element in $\mathrm{R} 7-57$ reporter cells. BZLF 1, transiently expressed in R7-57 reporter cells, was the only EBV trans-activator found, sufficient in inducing the viral lytic cycle. Basing on these experiments, trans-cellular activation of EBV was tested by cocultivation of BZLF 1-expressing R59Z activator cells with the R7-57 reporter line. No lytic effect on the reporter cells could be measured, neither by cocultivation of activator cells nor by coincubation of BZLF 1-containing cell lysates. Latency breaking activity, however, was transferred from activator to reporter cells when active, exogenous virus was added. The cell system described in these experiments provides a tool for the detection of EBV reactivation and demonstrates the potential of the lytic regulatory gene BZLF 1 .
\end{abstract}

\section{Introduction}

The regulation of the replicative cycle in Epstein-Barr virus (EBV) infection, i.e., establishment of latency or initiation of the lytic cascade, is subject to complex interactions between viral and cellular genes and gene products. In 
vivo, the spread of EBV is coordinated with the lytic activity in two cell pools: B-lymphocytes tend to maintain latent EBV genomes, whereas certain epithelial cells favour the switch to lytic reproduction. Various in vitro experiments suggested an interlocking of cellular and viral processes in gene activation. External stimuli on the host cell $[16,29,31]$ were shown to initiate the expression of viral immediate early trans-activators, e.g. BZLF 1 (Bam HI Z left frame 1) [3, 9]. As a consequence products of the early lytic gene cascade are started being expressed and convert the EBV genome from the latent to the lytic state [5, 6]. As a secondary function, the viral trans-activators possibly feed back to regulation of the host cell [28].

Experimental activation of EBV, as described in the culture systems below, gives insight the viral response to cellular changes. The resident, mutated EBV genome of Raji cells, which is maintained in the latent phase over long periods, can be induced to express the viral immediate early and early cascade $[11,16]$. Our Raji test system was based on the activity of the ori $L y t$ regulatory element. Ori $L y t$ was characterized as a bifunctional element, acting as origin of DNA replication [10] as well as a divergent promoter complex [7]. Both functions remain silenced during latency and are induced with the lytic switch of the genome. Transcriptional activation of recombinant ori $L y t$ was utilized to drive a reporter construct in Raji cells underlying inducing culture conditions.

BZLF 1 plays the key role in the transmission of inducing signals from the host cell towards the replicative activation of the viral genome $[15,17,26]$. Besides up-regulation of viral regulatory genes in a cascade-like manner, direct trans-activation of ori $L y t$ by the BZLF 1 product was reported $[7,13]$. In different cell types the expression of BZLF 1 appeared immediately linked to virus production, indicating its essential role in the lytic cycle. Detailed analysis of EBV antigens in tissues of oral hairy leukoplakia (OHL) revealed abundant BZLF 1 production in immature, differentiating cells [2]. In these OHL layers, virus multiplication was obviously suppressed, but characteristic lesions of neighbouring cells, termed koilocytosis, were repeatedly described $[2,19,33]$. EBV immediate early gene expression seems to lead, directly or indirectly, to a signal which influences tissue cells in nearest proximity. Furthermore it is an open question whether the BZLF 1 trans-activator can spread the lytic transition of EBV in a trans-cellular manner, as reported for other viral regulatory proteins, e.g., HIV Tat [14].

\section{Materials and methods}

\section{Construction of eukaryotic vectors}

Plasmids were constructed with the ability to persist in eukaryotic cells in an episomal form, based on the elements of EBV replication [21, 32], i.e., plasmid p 220.2 (supplied by Bill Sugden, McArdle Laboratory, University of Wisconsin, Madison, U.S.A.). The specific DNA sequences were introduced into the polylinker of $\mathrm{p} 220.2$, using restriction sites Bam HI/Hin d III (pEBV 57) and Bam HI/Sal I (pEBV 59), respectively. Subcloning of the original viral sequences was described elsewhere: HBsAg coding sequence [22], BZLF 1 
coding sequence [23] and CMV immediate early promoter-enhancer [4]. The ori $L y t$ regulatory element was subcloned as a 1060 bp fragment from the EBV Bam HI H clone [1, 30] using Hin cII and Apa LI restriction sites.

\section{Selection of recombinant cells}

Raji cells (Burkitt's lymphoma) were transfected by the DEAE dextran technique [24] with simple modifications [22]. Positive clones were selected for hygromycin B resistance, encoded by pEBV 57 and pEBV 59. Two days posttransfection the cells were exposed to increasing concentrations of hygromycin B. At each change of medium 50 to $200 \mu \mathrm{g} / \mathrm{ml}$ were added. Resistant cells were centrifuged in Ficoll gradients (density 1,077) to remove cell debris. The selection was repeated until the culture remained unimpaired during antibiotic treatment.

\section{Virus strains}

P3HR-1 cells (Burkitt's lymphoma) and B 95-8 cells (marmoset lymphocytes, in vitro converted with EBV) were used as EBV producer lines. The cultures were grown in RPMI 1640 medium with $10 \%$ heat-inactivated foetal calf serum, $100 \mathrm{units} / \mathrm{ml}$ of penicillin and $250 \mu \mathrm{g} /$ $\mathrm{ml}$ of streptomycin, at $37^{\circ} \mathrm{C}$. Virus production was induced chemically by treatment with $40 \mathrm{nM}$ of TPA and $3 \mathrm{mM}$ of butyric acid with an additional stimulatory temperature shift to $32{ }^{\circ} \mathrm{C}$ and serum reduction to $5 \%$ for 10 days. Virus stocks were prepared by ultracentrifugation of the supernatant at $20,000 \times \mathbf{g}$ for $2 \mathbf{h}$. See legends of Figs. 3 and 4 for details of infection experiments.

\section{In situ hybridization}

In situ hybridization was used to detect transfected DNA in lymphocytes. Stationary resting cells were rinsed in phosphate-buffered saline (PBS), spotted onto degreased microscope slides and fixed in $4 \%$ paraformaldehyde, $7.2 \mathrm{mg} / \mathrm{ml}$ of $\mathrm{NaCl}, 0.43 \mathrm{mg} / \mathrm{ml}$ of $\mathrm{KH}_{2} \mathrm{PO}_{4}$, $1.5 \mathrm{mg} / \mathrm{ml}$ of $\mathrm{Na}_{2} \mathrm{HPO}_{4}, \mathrm{pH} 7.3$ for $2.5 \mathrm{~min}$ at room temperature. Slide preparations were rinsed in PBS and treated with proteinase $\mathrm{K}(1 \mu \mathrm{g} / \mathrm{ml}$ in $10 \mathrm{mM}$ Tris / $1 \mathrm{mM}$ EDTA, pH 7.4) for $15 \mathrm{~min}$ at $37^{\circ} \mathrm{C}$. Following a second fixation step for $30 \mathrm{~min}$, the cell areas were prehybridized with hybridization mixture $(6 \times \mathrm{SSC}, 5 \times$ Denhardt's reagent, $45 \%$ formamide $)$ containing $100 \mu \mathrm{g} / \mathrm{ml}$ of denatured salmon sperm DNA for $15 \mathrm{~min}$ at $42^{\circ} \mathrm{C}$ [27]. After careful removal of the prehybridization mixture, $30 \mathrm{ng}$ of digoxigenin-labeled probe DNA (denatured at $90^{\circ} \mathrm{C}$ for $10 \mathrm{~min}$ ) per $30 \mu 1$ of hybridization mixture were placed on each spot of cells (denatured for 5 min on a heating block before rapidly put on ice). For probe specificity see legend of Fig. 2. Coverslips were mounted, sealed with rubber cement and hybridization was carried out in a humid chamber at $42^{\circ} \mathrm{C}$ overnight. The subsequent immunological colour detection was performed according to the standard protocol by Boehringer Mannheim (nonradioactive DNA labeling and detection kit).

\section{Immunofluorescence and Western blot}

For indirect immunofluorescence, transfected cells were fixed in ice-cold acetone for $5 \mathrm{~min}$. Human antisera and secondary fluorescein isothiocyanate-linked goat anti-human antibodies (Medac) were applied each at a dilution of $1: 50$ for $1 \mathrm{~h}$ at $37^{\circ} \mathrm{C}$. Each incubation was stopped by rinsing twice with ice-cold PBS for $15 \mathrm{~min}$. The slides were analyzed under the microscope at a magnification of 250 . For Western blots, the applied standard immunotechniques and staining procedures were described previously [23]. 
M. Marschall et al.

\section{Radioimmunoassay and enzyme-linked immunoassay}

Radioimmunoassay was used to quantitate the activity of promoter elements, as described for the HBsAg (hepatitis B virus surface antigen) reporter system [22]. In brief, recombinant HBsAg, used as reporter protein, was secreted from transfected cells. HBsAg production was assayed in supernatant aliquots by the commercially available radioimmunoassay (Abbott). Since cell lysis was not required, transfection assays could be monitored continuously over a period of time.

The nonradioactive quantitation of reporter protein was performed by an enzymelinked immunoassay (Abbott) using peroxidase-conjugated, secondary antibodies. The peroxidase substrate was incubated for $30 \mathrm{~min}$ in the dark before the optical density at $492 \mathrm{~nm}$ was determined.

\section{Results}

The establishment of recombinant cell systems allows the analysis of mechanisms involved in EBV reactivation by indirect, quantitative methods. Two episomal constructions, as shown in Fig. 1, were stably introduced into cell culture: pEBV 57 was based on the artificial linkage of the EBV ori Lyt element, upstream to the HBsAg coding sequence. Transcriptional activity of ori Lyt was monitored by HBsAg reporter expression [22]. pEBV 59 encoded the EBV BZLF 1 transactivator (Zta) under constitutive control of the CMV immediate early promoter-enhancer. BZLF 1 expression was analyzed in its capability to induce the EBV lytic cycle in B-lymphocytes. Raji cells were chosen as targets, because of their permanent latent infection with a mutated, nonproductive EBV strain [11].

Hygromycin B-resistant cell clones (R7-57 and R59Z), each carrying one of the episomal constructions (pEBV 57 and pEBV 59) were selected. The stability

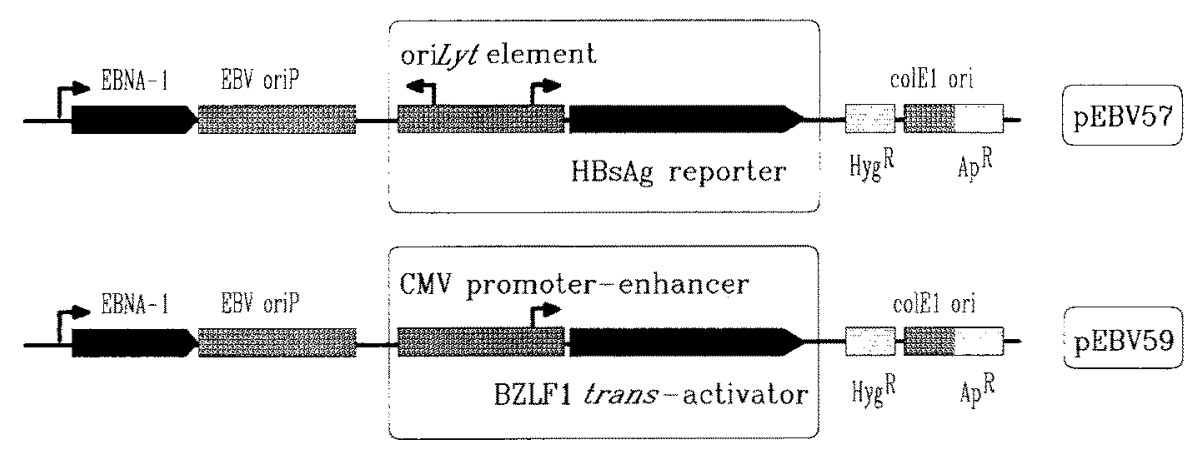

Fig. 1. Eukaryotic vectors selected in recombinant cells. The vectors used in these experiments were based on three sets of modules: (i) Origins of DNA replication for eukaryotic (EBV ori $P$ in cis and EBNA-1 in trans) [32] and prokaryotic cells (col El ori), (ii) antibiotic selection markers for eukaryotic (hygromycin B) and prokaryotic cells (ampicillin) and (iii) inserted test genes (ori $L y t$ element::HBsAg reporter or CMV promoter-enhancer::BZLF 1 trans-activator, respectively). The vectors pEBV 57 and pEBV 59, drawn in their linear organization, are maintained in the cell in a circular form. $E B N A$ Epstein-Barr virus nuclear antigen; ori origin of replication; $H B S A g$ hepatitis B virus surface antigen; $C M V$ cytomegalovirus; $B Z L F 1$ Bam $\mathrm{HI} \mathrm{Z}$ left frame 1 


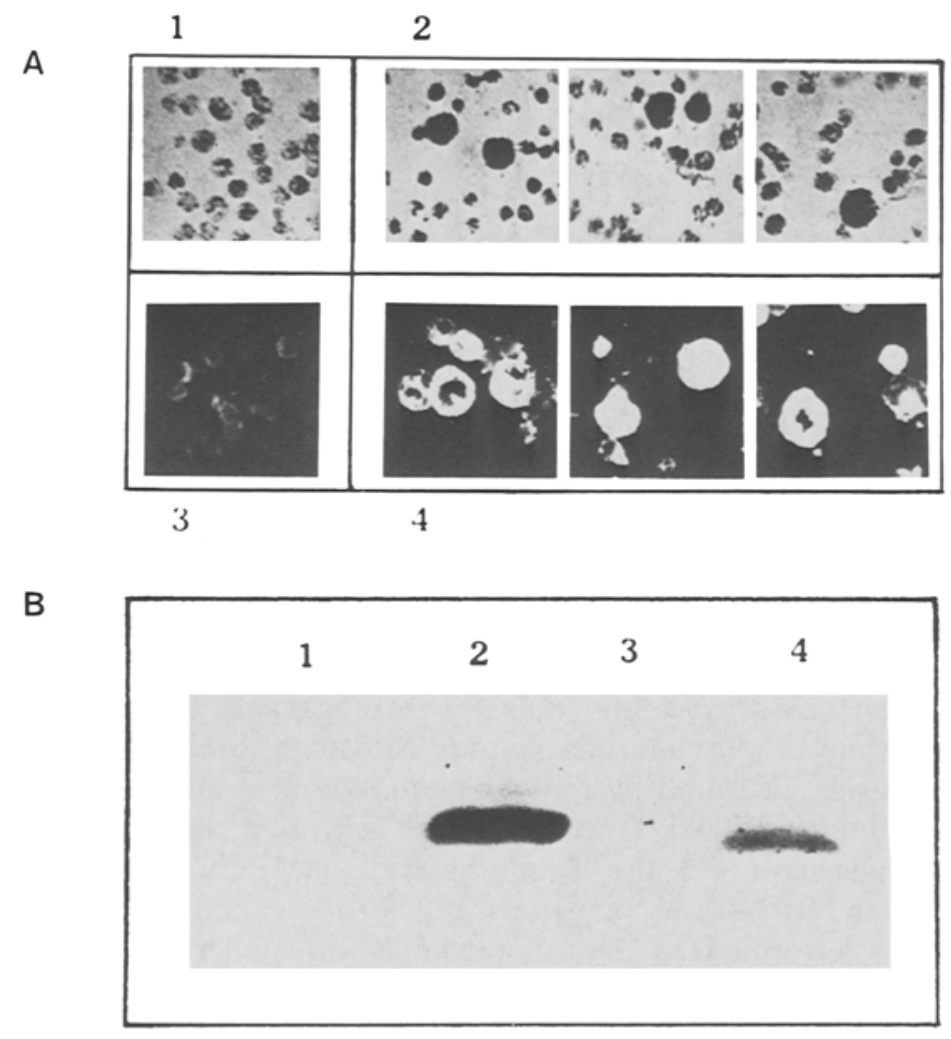

Fig. 2. Recombinant Raji cells (R7-57-pEBV 57 and R59Z-pEBV 59) replicating and expressing eukaryotic vectors. A In situ hybridization was performed with Raji (1) and R757 cells (2) screening for pEBV 57. A $900 \mathrm{bp} \mathrm{Bam} \mathrm{HI} \mathrm{fragment} \mathrm{of} \mathrm{the} \mathrm{HBsAg} \mathrm{sequence}$ which was labeled with digoxigenin was used as hybridization probe. Representative positive signals from three independent, parallel assays are shown in 2. Using human antisera of HBV-positive donors, immunofluorescence analysis of HBsAg was performed in latent R757 cells (3) and after lytic superinfection with P3HR-1 virus for 2 days (4, positive signals from three parallel assays). For details of superinfection see legend of Fig. 3. B Western blotting of cell extracts assayed for BZLF 1 protein using a monospecific rabbit antiserum: 1 Raji, 2 Raji superinfected with P3HR-1 virus, 3 R59Z before selection, 4 R59Z after selection. Note the strain-specific size variation between superinfecting P3HR-1 type and recombinant B 95-8 type BZLF 1 [5]

of the recombinant DNA was demonstrated by in situ hybridization. As shown in Fig. $2 \mathrm{~A}$, panel 2, typically large, blast-like cells gave strong, positive hybridization signals after antibiotic selection. Full functional integrity of the inserted test genes was analyzed by detection of their protein expression. The ori $L y t$ element remained in its inducible form (Fig. 2A, panel4), while the BZLF 1 protein was expressed in a constitutive way (Fig. 2 B).

R7-57 cells served as a stable reporter line for the lytic transition of the viral genome (Fig. 3). Untreated cells stayed exclusively in the latent phase. Accordingly the reporter level remained at a very low background. Chemical induction with TPA led to the accumulation of the reporter protein, promoted from an 


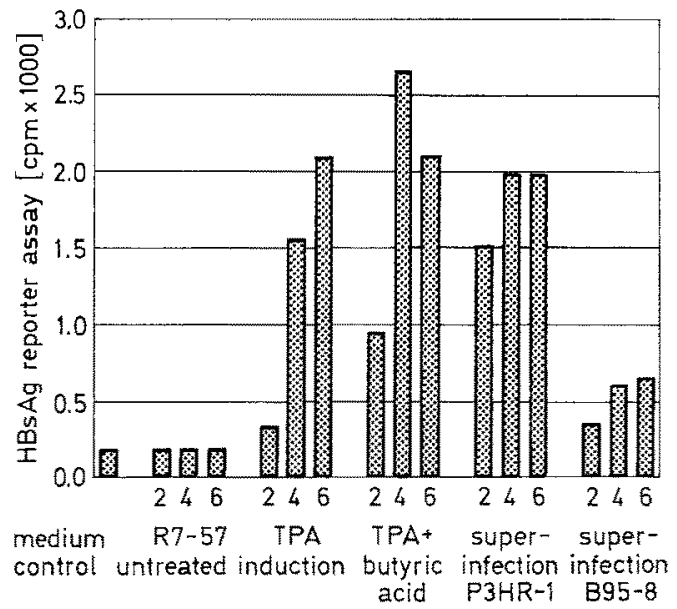

a

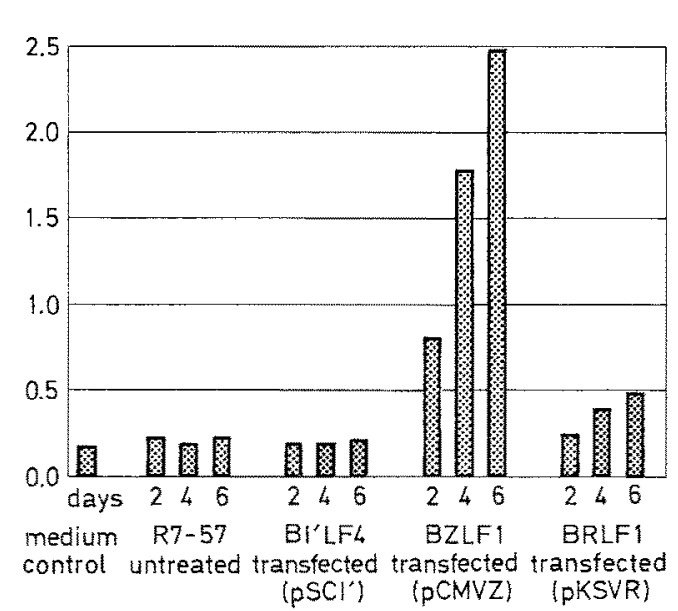

b

Fig. 3. HBsAg reporter assay (see Materials and methods) with R7-57 cells after chemical induction or superinfection (a) and specific trans-activation (b). Expression of the HBsAg reporter sequence was measured by radioimmunoassay 2,4 and 6 days after test start (absolute values in cpm $\times 1000$ ). R7-57 cells were cultivated either untreated or induced with the agents indicated (TPA $40 \mathrm{nM}$, butyric acid $3 \mathrm{mM}$ ). Superinfection of $10^{7} \mathrm{R} 59 \mathrm{Z}$ cells with P3HR-1 and B 95-8 virus, prepared from the supernatant of $10^{8}$ chemically induced producer cells, was performed for $1 \mathrm{~h}$ at room temperature under gentle movement. Transfections were done with $10 \mu \mathrm{g}$ of DNA per $10^{7}$ cells according to the DEAE dextran protocol $[22,24]$. Transient expression vectors for BZLF 1, BI'LF 4 (pCMVZ, pSCI') [23] and BRLF 1 (pKSVR) [20] were applied in equimolar concentrations. One third of each $10 \mathrm{ml}$ culture volume was taken every two days as an aliquot for assay. Values represent one experiment out of three reproductions

active ori $L y t$ element. Butyric acid was noted to increase the stimulation by TPA. Superinfection of R7-57 cells with EBV preparations resulted likewise in lytic signals. Strain-specific differences (P3HR-1, B 95-8) were quantified for the level of viral reactivation. In a transfection experiment using transient expression vectors encoding single EBV trans-activators, specific lytic effects became evident (trans-activators BZLF 1, BRLF 1, and BI'LF 4, i.e., left frame gene products of the EBV genome fragments $\operatorname{Bam} \mathrm{HI} \mathrm{Z}, \mathrm{R}$, and I'). The main EBV trans-activator BZLF 1 [5] gave rise to a strong lytic response. In contrast to this, the BRLF 1 product, known to activate transcriptional elements of the EBV early regulatory level $[7,13]$ reacted comparably low. The quantitative differences between these two viral proteins indicate the experimental discrimination between a direct, low-level trans-activator of ori Lyt (BRLF 1) and the full lytic transition by a latency breaking gene (BZLF 1). Furthermore, expression of BI'LF 4, described as an additional, specialized regulator of EBV genes [23] did not lead to a measurable lytic effect in this cell system.

The possibility of trans-cellular activation of the lytic cycle was assayed in a cocultivation experiment (Fig. 4). R59Z cells were used as activator line, directed towards the reporter line R7-57. Separate cultivation of either of the 


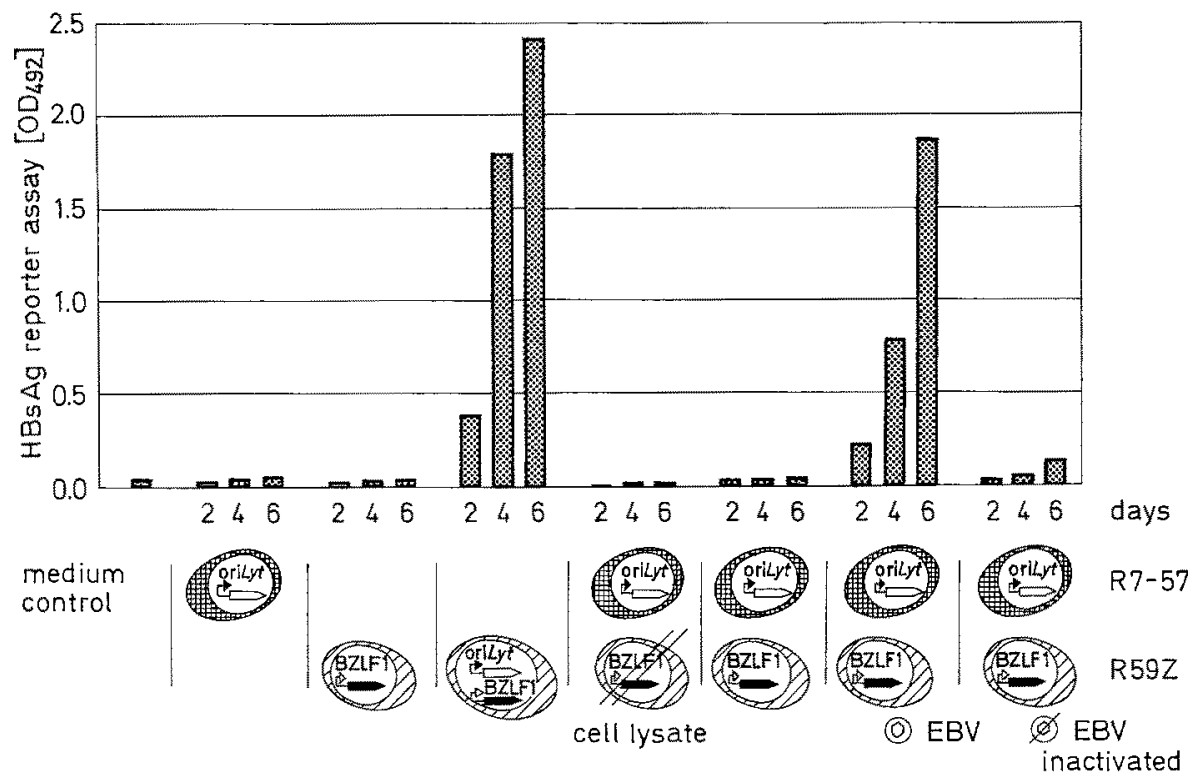

Fig. 4. HBsAg reporter assay with R7-57 and R59Z cells in coculture. Expression of the HBsAg reporter sequence was measured by enzyme-linked immunoassay 2,4 and 6 days after test start (absolute values $\mathrm{OD}_{492}$ ). The cells were cultured separately or in coculture at an initial cell density of $10^{7}$ per $10 \mathrm{ml}$ medium. Transfections were done with $10 \mu \mathrm{g}$ of DNA per $10^{7}$ cells according to the DEAE dextran protocol $[22,24]$. R59Z cell lysates were produced by sonication and were incubated in a 5 fold excess (lysate of $5 \times 10^{7} \mathrm{R} 59 \mathrm{Z}$ cells per $10^{7} \mathrm{R} 7-57$ cells). $10^{7} \mathrm{R} 59 \mathrm{Z}$ cells were superinfected with virus, prepared from the supernatant of $10^{8}$ P3HR-1 producer cells, for $1 \mathrm{~h}$ at room temperature under gentle movement. Virus preparations were inactivated by exposing to ultraviolet light at $302 \mathrm{~nm}$, $180 \mathrm{~W}$ at a distance of $5 \mathrm{~cm}$ for $10 \mathrm{~min}$. One third of each $10 \mathrm{ml}$ culture supernatant was taken every two days as an aliquot for assay. Values represent one experiment out of three reproductions

two cell types did not show reporter effects. As a control, both relevant plasmids were introduced into one cell, leading to the BZLF 1 response as described above. Incubation of BZLF 1-containing cell lysates did not influence the R757 reporter line, nor did recombinant BZLF 1 protein, produced in $E$. coli in abundance (not shown). In the same way, no lytic effect was measured by direct cocultivation of R59Z with R7-57 cells. The latent stabilization was not broken before R59Z cells were superinfected with lytic P3HR-1 virus prior to cocultivation. In this case, clear lytic activation was transferred from cell to cell, presumably resulting from the second round of infection by free virus. Subsequent inactivation of the superinfecting virus by irradiation largely eliminated the trans-cellular effect, thereby confirming this concept.

\section{Discussion}

The switch between latency and reproduction is a common strategy used by various viruses and points out the close adaptation of viral gene regulation to 
its specific host cell [12]. In the case of Epstein-Barr virus the elements determining the latent or lytic course of infection (EBNA-1/ori P or BZLF 1/ori Lyt, respectively) have been characterized and interpreted [25]. For analyzing the sequence of events in the infected cell, we established recombinant lymphocytes imitating specific steps of the lytic cycle. Introducing the ori $L y t$ element into a stable reporter construct we demonstrated an inducible lytic system which was strictly repressed under latent conditions. Coordinated lytic transition of R7-57 reporter cells was induced experimentally in various ways, e.g., incubation with chemical inducers, superinfection with lytic EBV or transient transfection with BZLF 1. Our test system, in essence, combines direct trans-activation of the recombinant ori $L y t$ element and amplification due to early EBV gene products activated from the intact part of the Raji genome.

Previous contradictory results prompted us to analyze the hypothetical, trans-cellular activity of BZLF 1, possibly directed towards the viral genome or the cell regulation: Replicative activation of EBV by BZLF 1 was demonstrated to be independent from further viral proteins of the lytic cycle [5]. The question remained whether BZLF 1 protein could, beyond that, cause cellular changes. Such assumptions seemed possible either directly via BZLF 1 protein, shed from destroyed cells as a consequence of a productive cycle of virus replication, or alternatively via induction of secreted, cellular factors. In epithelial cells of oral hairy leukoplakia, abundant typically cytoplasmic expression of BZLF 1 was detected in undifferentiated layers [2,33]. Remarkably, transregulatory effects which normally lead to the synthesis of succeeding lytic cascade proteins did not occur in these cells. On the other hand, morphological alteration of attached, EBV-negative cells (unpubl. results) were described as koilocytic lesions [19]. Furthermore in analogy to retroviral, replicative transactivators, cell to cell-mediated effects of BZLF 1 seemed to be possible. Tat protein of HIV-1 was reported to regulate the HIV LTR promoter on the one hand and to interfere with cellular growth regulation on the other hand in trans-cellular route $[8,14]$. Extracellular Tax ${ }_{1}$ of HTLV-1 was shown to regulate the expression of endogenous cellular genes [18].

We therefore constitutively expressed the latency breaking gene of EBV, BZLF 1, in R59Z activator cells in a trans-active and noncytotoxic form. Our experiments demonstrate that carefully directed cocultivation of BZLF 1-expressing cells with reporter cells did not induce lytic EBV expression. Neither BZLF 1 itself nor BZLF 1-induced gene products of the resident Raji genome affected viral latency in cocultured cells. Cell-free BZLF 1 protein did likewise not influence the endogenous EBV genome and neither were changes detected in the cellular growth behaviour or morphology. In contrast to this, lytic transition of reporter cells was induced from cell to cell when superinfected activator cells were added. This effect was shown to be dependent on complete virus replication and release of lytic particles because inactivation of the superinfecting virus did significantly reduce the reporter signal of the cocultivated cells.

Our observations state $(i)$ that the dimension of lytic EBV production can 
directly be correlated to ori $L y t$ activity, (ii) that ori $L y t$ activity depends on the induction of cellular pathways and on defined viral trans-activators and (iii) that BZLF 1 is an efficient intracellular activator, but does not influence cocultured lymphocytes. This does not exclude the possibility of participation of BZLF 1 in cellular gene regulation and specific effects in non-lymphoid host cell types. Regulatory consequences of abundant and exclusive BZLF 1 production in epithelial tissues, i.e., the presumed correlation to koilocytosis formation, have to be studied further.

\section{Acknowledgements}

The authors are grateful to Bill Sugden (McArdle Laboratory, University of Wisconsin, Madison, U.S.A.) for kindly providing plasmid p 220.2. We thank Alain Sergeant and collaborators (École Normale Supérieure de Lyon, Lyon, France) for very competent and open discussion and cooperation.

\section{References}

1. Baer R, Bankier AT, Biggin MD, Deininger PL, Farell P, Gibson TJ, Hatfull G, Hudson GS, Satchwell SC, Seguin C, Tuffnell PS, Barrell BG (1984) DNA sequence and expression of the B 95-8 Epstein-Barr virus genome. Nature 310: 207-211

2. Becker J, Leser U, Marschall M, Langford A, Jilg W, Gelderblom H, Reichart P, Wolf H (1991) Expression of proteins encoded by Epstein-Barr viral trans-activator genes depends on the differentiation of epithelial cells in oral hairy leukoplakia. Proc Natl Acad Sci USA 88: 8332-8336

3. Biggin M, Bodescot M, Pericaudet M, Farrell P(1987) Epstein-Bar virus gene expression in P3HR1-superinfected Raji-cells. J Virol 61: 3120-3132

4. Boshart M, Weber F, Jahn G, Dorsch-Häsler K, Fleckenstein B, Schaffner W (1985) A very strong enhancer is located upstream of an immediate early gene of human cytomegalovirus. Cell 41: 521-530

5. Countryman J, Jenson H, Seibl R, Wolf H, Miller G (1987) Polymorphic proteins encoded within BZLF 1 of defective and standard Epstein-Barr viruses disrupt latency. J Virol 12: 3672-3679

6. Countryman J, Miller G (1985) Activation of expression of latent Epstein-Barr herpesvirus after gene transfer with a small cloned subfragment of heterogeneous viral DNA. Proc Natl Acad Sci USA 82: 4085-4089

7. Cox MA, Leahy J, Hardwick MJ (1990) An enhancer within the divergent promoter of Epstein-Barr virus responds synergistically to the $\mathrm{R}$ and $\mathrm{Z}$ transactivators. J Virol 64: $313-321$

8. Ensoli B, Barillari G, Salahuddin SZ, Gallo RC, Wong-Staal F (1990) Tat protein of HIV-1 stimulates growth of cells derived from Kaposi's sarcoma lesions of AIDS patients. Nature $345: 84-86$

9. Flemmington E, Speck S (1990) Identification of phorbol ester response elements in the promoter of Epstein-Barr virus putative lytic switch gene BZLF 1. J Virol 64: 12171226

10. Hammerschmidt W, Sugden B (1988) Identification and characterization of ori $L y t$, a lytic origin of DNA replication of Epstein-Barr virus. Cell 55: 427-433

11. Hatfull G, Bankier AT, Barrel BG, Farrell PJ (1988) Sequence analysis of Raji EpsteinBarr virus DNA. Virology 164: 334-340 
12. Garcia-Blanco MA, Cullen BR (1991) Molecular basis of latency in pathogenic human viruses. Science 254: 815-819

13. Gruffat H, Moremo N, Sergeant A (1990) The Epstein-Barr virus (EBV) $\mathrm{ORI}_{1 \mathrm{yt}}$ enhancer is not B-cell specific and does not respond synergistically to the EBV transcription factors $\mathrm{R}$ and $\mathrm{Z}$. J Virol 64: 2810-2818

14. Helland DE, Welles JL, Caputo A, Haseltine WA (1991) Transcellular transactivation by the human immunodeficiency virus type 1 tat protein. J Virol 65: 4547-4569

15. Katz DA, Baumann RP, Sun R, Kolman JL, Taylor N, Miller G (1992) Viral proteins associated with the Epstein-Barr virus transactivator, ZEBRA. Proc Natl Acad Sci USA 89: $378-382$

16. Laux G, Freese UK, Fischer R, Polack A, Kofler E, Bornkamm GW (1988) TPAinducible Epstein-Barr virus genes in Raji cells and their regulation. Virology 162: 503507

17. Liebermann PM, Berk AJ (1990) In vitro transcriptional activation, dimerization and DNA-binding specificity of the Epstein-Barr virus Zta protein. J Virol 64: 2560-2568

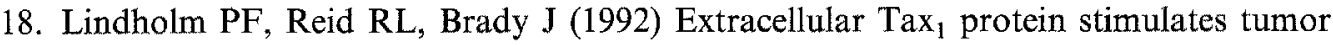
necrosis factor- $\beta$ and immunoglobulin kappa light chain expression in lymphoid cells. J Virol 66: 1294-1302

19. Loning T, Henke RP, Reichart R, Becker J (1987) In situ hybridisation to detect Epstein-Barr virus DNA in oral tissues of HIV-infected patients. Virchows Archiv 412: 127-133

20. Manet E, Gruffat H, Trescol-Biemont M, Moreno N, Chambard P, Giot J, Sergeant A (1989) Epstein-Barr virus bicistronic mRNAs generated by facultative splicing code for two transcriptional trans-activators. EMBO J 8: 1819-1826

21. Margolskee RF, Kavathas P, Berg P (1988) Epstein-Barr virus shuttle vector for stable episomal replication of cDNA expression libraries in human cells. Mol Cell Biol 8: 2837-2847

22. Marschall M, Motz M, Leser U, Schwarzmann F, Oker B, Wolf H (1989) Hepatitis $B$ virus surface antigen as a reporter of promoter activity. Gene 81: 109-117

23. Marschall M, Schwarzmann F, Leser U, Oker B, Allinger P, Mairhofer H, Wolf $\mathrm{H}$ (1991) The BI'LF 4 trans-activator of Epstein-Barr virus is modulated by type and differentiation of the host cell. Virology 181: 172-179

24. McCutchan JH, Pagano JS (1968) Enhancement of the infectivity of simian virus 40 deoxyribonucleic acid with diethylaminoethyl-dextran. J Natl Cancer Inst 41: 351-357

25. Miller $\mathbf{G}$ (1990) The switch between latency and replication of Epstein-Barr virus. J Infect Dis 161: 833-844

26. Montalvo EA, Shi Y, Shenk TE, Levine A (1991) Negative regulation of the BZLF 1 promoter of Epstein-Barr virus. J Virol 65: 3647-3655

27. Sambrook J, Fritsch E, Maniatis T (1989) Molecular cloning: a laboratory manual, second edition. Cold Spring Harbor Laboratory Press, Cold Spring Harbor

28. Sato H, Takeshita H, Furukawa M, Seiki M (1992) Epstein-Barr virus BZLF 1 transactivator is a negative regulator of jun. J Virol 66: 4732-4736

29. Schuster C, Chasserot-Golat S, Beck G (1991) Activation of Epstein-Barr virus promoters by a growth-factor and a glucocorticoid. FEBS 284: 82-86

30. Skare J, Strominger JL (1980) Cloning and mapping of Bam HI endonuclease fragments of DNA from the transforming B 95-8 strain of Epstein-Barr virus. Proc Natl Acad Sci USA 77: $3860-3864$

31. Takada K, Ono Y (1989) Synchronous and sequential activation of latently infected Epstein-Barr virus genomes. J Virol 63: 445-449

32. Yates JL, Warren N, Sugden B (1985) Stable replication of plasmids derived from Epstein-Barr virus in various mammalian cells. Nature 313: 812-815

33. Young LS, Lau R, Rowe M, Niedobotek G, Packham G, Shanahan F, Rowe DT, 
Greenspan D, Greenspan JS, Rickinson AB, Farrell PJ (1991) Differentiation-associated expression of the Epstein-Barr virus BZLF 1 transactivator protein in oral hairy leukoplakia. J Virol 65: 2868-2874

Authors' address: Dr. M. Marschall, Abteilung für Virologie, Institut für Medizinische Mikrobiologie und Hygiene, Technische Universität München, Biedersteinerstrasse 29, D-W-8000 München, Federal Republic of Germany.

Received May 19, 1992 